\title{
Performance of Broilers Supplemented with Natural Herb Extract
}

\author{
J. Abo Omar1 ${ }^{*}$, A. Hejazi'2, R. Badran ${ }^{3}$ \\ ${ }^{1}$ An-Najah National University, Nablus, Palestine \\ ${ }^{2}$ Ministry of Agriculture, Tulkarm Governorate, Palestine \\ ${ }^{3}$ Bajjora Company, Dier El Ghosoun, Palestine \\ Email: *aboomar57@najah.edu
}

Received 19 November 2015; accepted 17 January 2016; published 20 January 2016

Copyright (C) 2016 by authors and Scientific Research Publishing Inc.

This work is licensed under the Creative Commons Attribution International License (CC BY). http://creativecommons.org/licenses/by/4.0/

(c) (i) Open Access

\section{Abstract}

The objective of this research was to investigate the effects of a natural herb extract on the general performance, carcass parameters and mortality of broiler chicks. A total of 720 one-day old chicks (Cobb 500) were used in the experiment and randomly partitioned into nine pens ( 80 chicks per pen). Three experimental diets (C: regular starter feed; CC plus: regular starter feed supplemented with chicken plus herbal extract; AFC plus: antibiotic-free diet supplemented with chicken plus) were assigned each to three randomly selected pens. The herbal extract was supplemented in drinking water at rate of $300 \mathrm{ml} /$ cubic meter. Results showed that weights, feed conversion ratios (FCR) and dressing percentages (DP) increased $(P<0.05)$ in birds supplemented with herb extract compared to control birds. Mortalities and sudden deaths were minimized via herbal supplementation. However, herbal supplementation had no significant effects on carcass cuts and some visceral organs. The relative economic efficiency (REE) was up to $13 \%$ improved by the herb supplementation. It can be concluded that feeding the herbal extract has significant positive effects on broilers general performance as feed efficiency is increased by $11 \%$ and on mortality and sudden death cases.

\section{Keywords}

Herb Extract, Broilers, Feed Conversion Ratio (FCR), Performance, Carcass Cuts

\section{Introduction}

Since long time, antibiotics (growth promoters) in animal feeds under intensive farming had positive impact on

${ }^{*}$ Corresponding author. 
feed conversion efficiency. The use of antibiotics in broilers feeds has been limited in the European Union and many other regions of the world. A manipulation of gut function and microbial habitat of domestic animal with feed additives has been recognized as an important tool for improving growth performance and feed efficiency [1]. Approximately $80 \%$ of domestic animals have been fed synthetic compounds for the purpose of either medication or growth promotion [2]. The banning of the use of antibiotics as feed additives has accelerated and led to find nontraditional feed additives to be used in animal feeds. Herbal extracts are being used as feed additives to improve animal performance especially under the intensive management systems [3]. Both health status and general performance can be supported by plant extracts [4]-[9]. The positive impact on animals health and performance could be achieved through the stimulation of appetite and feed intake, the improvement of endogenous digestive enzyme secretion, activation of immune response and, antiviral, antioxidant and antihelminthic actions. It was found that Fenugreek seeds are rich in protein, fat, total carbohydrates and minerals such as calcium, phosphorus, iron, zinc and magnesium [10]. Moreover Fenugreek benefits the digestive system [11].

Chamomile flowers inhibit the excessive growth of intestinal harmful microorganism, thus counteracting inflammation, [12]. Nettle (Urtica dioica) has been used to promote health. Numerous analyses of nettle have revealed the presence of more than fifty different chemical constituents. It has been extensively studied and found to contain starch, gum, albumen, sugar, and two resins. Histamine, acetylcholine, choline, and serotonin are also present. Thyme (Thymus vulgaris ) with the main components of Phenols, thymol (40\%) and carvacrol (15\%) [13]. This herb is also used traditionally for medicinal purposes [13].

Mentha species_ of the family labiatae — are being valued especially for its antiseptic properties and its beneficial effects on the digestion [14].

The pharmacological action of active plant substances or herbal extracts in humans is well known, but in animal nutrition the number of precise experiments is relatively low. The objective of this research was to investigate effects of a blended natural herb extract when supplemented to regular broiler and an antibiotic free broiler feed.

\section{Materials and Methods}

\subsection{Experimental Animals and Design}

A total of 720 one-day old chicks (Cobb 500) were purchased from a local hatchery. On arrival, chicks were weighed and randomly housed in wood shavings covered floor pens (80 chicks per pen). Continuous lighting was provided throughout the experiment. The ambient temperature was gradually decreased from $32^{\circ} \mathrm{C}$ on day 1 to $7^{\circ} \mathrm{C}$ to $24^{\circ} \mathrm{C}$ on day 21 and was then kept constant. A complete random design was used involving three dietary treatments and three replicates for each.

The formulas and calculated nutrient of the basal diet are presented in Table 1 . The starter diets were fed for the first three weeks and the grower diet was fed for the remainder of the trial (33 days). Chicken-plus ${ }^{1}$ was added at rate of $300 \mathrm{ml} / \mathrm{m}^{3}$ to drinking water starting from day 1 till termination of the feeding trial $(33 \mathrm{~d})$. Chicks were assigned to the basal diet (control, C) which is similar to regular broiler starter diets. While in treatment 2, birds were fed the diets as in control but was supplemented with the chicken plus (CC Plus). The third treatment chicks were fed an antibiotic free starter feed and supplemented with chicken plus (AFC plus). Broiler diets were formulated to meet the NRC [15] recommendations.

Feed consumption was recorded at weekly basis, by monitoring the feed offered and amounts remained at feeders at end of the week. Individual bird weight was also recorded weekly. Birds dying within the five days were replaced, afterwards, mortality was recorded as it occurred and dead chick weights were determined where possible.

Body weight, feed intake and feed conversion were assessed on days 21 and 33 or during the age ranges of 1 21 and 22 - 33 days. FCR was calculated as the following: FCR = average feed consumed/average live weight.

\subsection{Carcass Cuts}

At 33 days of age, five birds from each replicate were randomly chosen, slaughtered and carcass and some viscera organs percent to live weight and percent of carcass parts to carcass weight were calculated.

\footnotetext{
${ }^{1}$ Chicken-plus: a mixture of pure honey with an extract of several medicinal plants: fenugreek (Tigonella foenum graecum), chamomile
} (Anthemis ecutita), nettle (Urtica dioica), thyme (Thymus vulgaris), mint (Menthola), black seed (Nigella sativa). 
Table 1. Basal formula and calculated analysis of diets fed to broilers.

\begin{tabular}{|c|c|c|}
\hline Ingredient & Starter (\%) & Grower (\%) \\
\hline Yellow corn & 36 & 41 \\
\hline Wheat & 20 & 21 \\
\hline Soybean meal & 36 & 30.3 \\
\hline Oil & 4 & 4 \\
\hline $\mathrm{DCP}^{1}$ & 1.5 & 1.2 \\
\hline Limestone & 1.5 & 1.5 \\
\hline Salt & 0.35 & 0.35 \\
\hline Premix ${ }^{2}$ & 0.5 & 0.5 \\
\hline DL-methionine & 0.1 & 0.1 \\
\hline L-lysine & 0.05 & 0.05 \\
\hline Total & 100 & 100 \\
\hline \multicolumn{3}{|l|}{ Calculated analysis: } \\
\hline Crude protein & 22 & 20 \\
\hline Lysine & 11 & 11 \\
\hline Methionine & 5.5 & 5.6 \\
\hline Calcium & 10 & 11 \\
\hline Available $\mathrm{P}^{3}$ & 4.6 & 4.7 \\
\hline $\mathrm{ME}, \mathrm{MJ} / \mathrm{kg}$ diet & 704.5 & 718 \\
\hline
\end{tabular}

${ }^{1}$ Dicalcium phosphate. ${ }^{2}$ Vitamin premix/kg diet: vitamin A—12,000 IU; vitamin D3-1500 IU; vitamin E—50 mg; vitamin K3-5 mg; vitamin

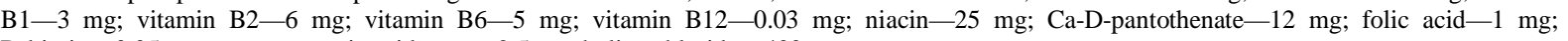
D-biotin-0.05 mg; apo-carotenoic acid ester-2.5 mg; holine chloride — $400 \mathrm{mg}$;

${ }^{2}$ The chemical analysis of GP (\%): Energy (cal/100 g), 332; protein, 16.8; moisture, 5.61; fat, 0.76; total ash, 3.18. Antibiotic was included in the ration in the control and CC plus groups, but was excluded from the ration fed to AFCplus birds. ${ }^{3}$ Phosphorus.

\subsection{Statistical Analysis}

Analysis of variance was used to test the significance of treatment effects. Differences among treatment means were tested using Tukey's HSD test with a significance level of 0.05. Carcass and visceral organ variables were expressed as percentages of live weights. These analyses were performed using SAS statistical analysis software [16]. Pearson correlation was used to test the relationship between pairs of continuous variables (i.e., feed conversion ratios, carcass and visceral organ variables). The basic unit of analysis was the average of broiler chicks comprising each replicate (except carcass traits where averages were obtained on 5 randomly selected chicks).

\section{Results}

The data which obtained from performance of broiler chickens fed by herbs and their combination are shown in Table 2. There were a significant effect on food intake of treated chicks $(\mathrm{P}<0.05)$. The highest amount of food intake were in birds consuming the chicken plus compared to the control birds consuming the regular broiler diets. At age of $33 \mathrm{~d}$ birds supplemented with the herb extract ate 10 and $12 \%$ more feed compared to the control birds. However, birds supplemented with the extract gained more $(\mathrm{P}<0.05)$ weight compared to birds consuming the regular broiler diet. At time of termination of the feeding trial (day 33) birds supplemented with the herb extract had 18 and 22\% increase in the average weights. Similar trend was observed in the FCR where it was higher $(\mathrm{P}<0.05)$ in birds supplemented with the herb extract.

Carcass and visceral organ variables were expressed as percentages of live weights. Table 3 shows the effect of extract on carcass and its parameters. According to the data, there were no significant differences in the carcass characters. However, there was a numerical differences among the tested parameters. The lowest percen- 
Table 2. The effects on body weight, feed intake, feed conversion ratios (FCR) in broilers fed the herb extract (chicken plus) with two feed formulas.

\begin{tabular}{cccc}
\hline Parameter & C $^{1}$ & CC plus & AFC plus \\
\hline Number of birds & 80 & 80 & 80 \\
Initial weight & 48 & 48 & 48 \\
Body weight at 21 d & $925^{\mathrm{b}, 2}$ & $1039^{\mathrm{a}}$ & $2101^{\mathrm{a}}$ \\
Body weight at 33 d & $1660^{\mathrm{b}}$ & $2019^{\mathrm{a}}$ & $1387^{\mathrm{a}}$ \\
Feed intake at 21 d & $1258^{\mathrm{b}}$ & $1326^{\mathrm{a}}$ & $3267^{\mathrm{a}}$ \\
Feed intake at 33 d & $2904^{\mathrm{b}}$ & $3218^{\mathrm{a}}$ & $1.26^{\mathrm{b}}$ \\
FCR at 21 d & $1.36^{\mathrm{a}}$ & $1.27^{\mathrm{b}}$ & $1.54^{\mathrm{b}}$ \\
\hline
\end{tabular}

${ }^{1} \mathrm{C}$ = control basal diet, CC plus = control basal diets supplemented with chicken plus $\left(300 \mathrm{ml} / \mathrm{m}^{3}\right)$, AFC plus = antibiotic free diet supplemented with chicken plus $\left(300 \mathrm{ml} / \mathrm{m}^{3}\right)$. ${ }^{2}$ Means in the same raw with different superscripts are significantly different $(\mathrm{P}<0.05)$ using Tukey's HSD test.

Table 3. Effects of the herb extract (chicken plus) when fed with tow feed formulas on the relative weights (\% of body weight) of some internal organs of broilers.

\begin{tabular}{cccc}
\hline Parameter & C $^{1}$ & CC plus & AFC plus \\
\hline Number of birds & 5 & 5 & 5 \\
Liver & 2.56 & 1.54 & 0.00 \\
Heart & 0.45 & 0.48 & 0.37 \\
Spleen & 0.11 & 0.11 & 0.07 \\
Gizzard & 2.51 & 2.40 & 1.82 \\
Fat pad & 1.57 & 1.30 & 1.24 \\
Bursa & 0.16 & 0.12 & 0.10 \\
Viscera & 7.12 & 6.60 & 5.37 \\
\hline
\end{tabular}

${ }^{1} \mathrm{C}=$ control basal diet, CC plus = control basal diets supplemented with chicken plus $\left(300 \mathrm{ml} / \mathrm{m}^{3}\right)$, AFC plus = antibiotic free diet supplemented with chicken plus $\left(300 \mathrm{ml} / \mathrm{m}^{3}\right)$.

tage of gizzard, bursa and spleen were in birds supplemented with the herb extract, especially when associated with feeds lacking growth promoters. Bursa relative weight was numerically the lowest in the control birds compared to the other two treatments $(0.10,0.12,0.16)$. Similar trend was observed for spleen where relative weights were $0.07,0.11$ and 0.11 for the control, birds fed regular or growth promoter deficient feeds, respectively.

Carcass cuts relative weights were not affected by type of treatment (Table 4). Feeds supplemented by the herb extract resulted in higher dressing proportions compared to control birds. The dressing proportions were $70.5 \%, 77.0 \%$ and $75 \%$ for the control, birds fed regular or growth promoter deficient feeds, respectively.

Mortality percent was around $3 \%$ and cases of sudden death were minimal (only 2 cases).

The results of economical efficiency (EF) and relative economical efficiency (REF) estimated for the experimental diets used during the experiment are shown in Table 5. According to the input-output analysis, the best R.E.E were recorded by the birds fed CC plus followed by birds fed AFC plus compared to the control birds.

\section{Discussion}

The initial live body weight of chicks at one-day old showed similar values with no significant differences among treatment groups. There were a significant effect on food intake of treated chicks. The highest amount of food intake were in birds consuming the C plus and AFC plus diets compared to the control birds consuming the 
Table 4. Effects of the herb extract (chicken plus) when fed with two feed formulas on the relative weights (\% of body weight) of some carcass cuts of broilers.

\begin{tabular}{cccc}
\hline Parameter & C $^{1}$ & CC plus & AFC plus \\
\hline Number of birds & 5 & 5 & 5 \\
Neck & 3.79 & 4.41 & 27.16 \\
Thye & 28.21 & 28.10 & 31.0 \\
Breast & 28.40 & 30.5 & 6.74 \\
Wings & 6.92 & 6.88 & $75.0^{\mathrm{a}}$ \\
\hline
\end{tabular}

${ }^{1} \mathrm{C}=$ control basal diet, CC plus = control basal diets supplemented with chicken plus $\left(300 \mathrm{ml} / \mathrm{m}^{3}\right)$, AFC plus = antibiotic free diet supplemented with chicken plus $\left(300 \mathrm{ml} / \mathrm{m}^{3}\right)$. ${ }^{2}$ Means in the same raw with different superscripts are significantly different $(\mathrm{P}<0.05)$ using Tukey’s HSD test.

Table 5. The economic evaluation of broilers fed herb extracts.

\begin{tabular}{|c|c|c|c|}
\hline Parameter & $\mathrm{C}^{1}$ & CC plus & AFC plus \\
\hline Feed cost/bird & 6.67 & 7.40 & 7.84 \\
\hline Selling revenue & 19.92 & 24.22 & 25.32 \\
\hline Net revenue & $13.25^{\mathrm{b}}$ & $16.82^{\mathrm{a}}$ & $17.48^{\mathrm{a}}$ \\
\hline Economic efficiency (EE) & $2.98^{\mathrm{b}, 2}$ & $3.27^{\mathrm{a}}$ & $3.22^{\mathrm{a}}$ \\
\hline Relative economic efficiency (REE) & $100^{\mathrm{b}}$ & $110^{\mathrm{a}}$ & $109^{\mathrm{a}}$ \\
\hline
\end{tabular}

${ }^{1} \mathrm{C}=$ control basal diet, CC plus = control basal diets supplemented with chicken plus $\left(300 \mathrm{ml} / \mathrm{m}^{3}\right)$, AFC plus = antibiotic free diet supplemented with chicken plus $\left(300 \mathrm{ml} / \mathrm{m}^{3}\right)$. ${ }^{2}$ Means in the same raw with different superscripts are significantly different $(\mathrm{P}<0.05)$ using Tukey’s HSD test.

regular broiler diets (C). The positive effects of herbs on body weight and general performance may be due to the presence of a mixture of essential fatty acids including linolenic and linoleic acids presented in some herbs, especially the black seeds which are essential for growth [17]. Toghyani et al. [18] reported that the low dosage $(5 \mathrm{~g} / \mathrm{Kg})$ of Thyme have significant effect on broiler body weight and their feed conversion ratio. Najafi et al. [19] reported that the group which fed by thyme-included diet had significantly better body weight and feed conversion ratio, But Tekeli et al. [20] and Demir et al. [21] reported opposite results; they found that thyme has no influence on broilers performance.

Our findings showed that there was 8 to $11 \%$ improvement in FCR of birds supplemented with the herb extract. The improvement in protein utilization, absorption and suppression of gram negative bacteria and Cholostridium that cause growth depression might be the reason for the improvement in body weight and feed conversion ratios [22] [23]. El-Gendy et al. [24] reported that the improvement in feed conversion ratio with feeding herbal extract could be associated with improving the digestibility of dietary protein in the small intestine. The action of herbal extracts as antioxidants, anti bacterial, anti fungal and anti protozoa also add to the positive improvement in birds performance [25].

Several metabolites play the role in the physiological, chemical function of digestive tract and the microbial population in animals gut among these are the isoprene derivatives, flavonoids, glucosinolates and other plant metabolites may affect the physiological and chemical function of the digestive tract [5] [26] [27].

Our findings are in agreement with what was reported by [28]. Elbushra et al. [28] reported that live body weight at 6 weeks old, body weight gain, feed conversion ratio and protein efficiency ratio were significantly improved for chicks fed diets supplemented with fenugreek at rate of $0.5 \%$ or $1.5 \%$ as compared to control diet. Supplementation of fenugreek had significant effect for broiler chicks in live body weight, body weight gain, feed conversion ratio, protein efficiency ratio, feed consumption and efficiency of energy utilization [28]. Similarly, supplementation of chamomile flowers at level of $2.5 \mathrm{~kg} / \mathrm{ton}$ of broiler diet improved growth performance and feed conversion [29]. Chamomile (Matricaria Chamomilla L.) contains chemicals as flavones opigenin, essential oil such as bisaboloxide B, $\alpha$-bisabolol, chamazulene and bisababoloxide A [30]. 
According to our data, there were no significant differences in the carcass characters and visceral organ relative weights. However, there was a numerical differences among the tested parameters. However, the debate on the real effects of nettle on broilers performance can be explained by the nettle variety or chickens used, farm management and operations used in the rearing of broiler chickens. The carvacrol in nettle has stimulatory effects on pancreatic secretions [31] by increasing the secretions of digestive enzymes more amounts of nutrients like amino acids can be digested and absorbed from the digestive tract and thereby improve carcass traits.

The results of economical efficiency (EF) and relative economical efficiency (REF) estimated for the experimental diets used during the experiment are shown in Table 5. According to the input-output analysis, the best R.E.E were recorded by the birds fed CC plus followed by birds fed AFC plus compared to the control birds.

These results indicated that the diets containing herbal extract were more economical than the control diet. This improvement could be due to improving the feed conversion or reducing the amount of feed required to produce one unit of meat. These findings are in agreement with previous research where herbal extracts improved the economic evaluation [29] [32]-[34].

The recorded mortalities were $3 \%$ in average compared to that in commercial operations which is $5 \%-7 \%$. This reduction in broilers' mortalities could be explained by improvement in birds general performance and better build up of the immunity caused by the supplement.

\section{Conclusion}

The herb extract had several advantages when supplemented to broilers. Significant improvement in body weights, FCR and dressing percentages. The relative economic efficiency was up to $10 \%$ improved by the herb supplement. Our results were comparable to Cobb 500 standards and more.

\section{Acknowledgements}

The authors wish to thank Mr. Afif Tanous for his valuable support. Appreciation is extended to Dr. Nasouh Badran; Dr. Mohamad Badran and Mr. Ahmad Abu Al Rub for their endless assistance in many aspects of this project. The authors also thank the Bajjora Company and its staff.

\section{References}

[1] Collington, G.K., Park, D.S. and Armstrong, D.G. (1990) The Influence of Both an Antibiotic and a Probiotic in the Diet on the Development of Digestive Enzyme Activity in the Pig. British Journal of Nutrition, 64, 59-70. http://dx.doi.org/10.1079/BJN19900009

[2] Lee, M.H., Lee, H.J. and Ryu, P.D. (2001) Public Health Risks: Chemical and Antibiotic Residues Review. AsianAustralian Journal of Animal Science, 14, 402-413.

[3] William, P. and Losa, R. (2001) The Use of Essential Oils and Their Compounds in Poultry Nutrition. World's Poultry, 17, 14-15.

[4] Janssen, A.M. (1989) Antimicrobial Activities of Essential Oils: A Pharmacognostical Study. Dissertation, Rijks Universiteit, Leiden.

[5] Horton, G.M.J., Fennell, M.J. and Prasad, B.M. (1991) Effect of Dietary Garlic (Allium sativum) on Performance, Carcass Composition and Blood Chemistry Changes in Broiler Chickens. Canadian Journal of Animal Science, 71, 939-942. http://dx.doi.org/10.4141/cjas91-113

[6] Bakhiet, A.O. and Adam, S.E.I. (1995) Therapeutic Utility, Constituents and Toxicity of Some Medicinal Plants: A Review. Veterinary Human Toxicology, 37, 255-258.

[7] Skrabka-Blotnicka, T., Rosin’ski, A., Przysie-Zzna, E., Woloszyn, J. and Elminowska-Wenda, G. (1997) Effect of Dietary Formulation Supplemented with Herbal Mixture on Goose Breast Muscle Quality. Report I. The Effect on the Chemical Composition. Archives für Geflügelkunde, 61, 135-138.

[8] Gill, A., Delaquis, P. Russo, P. and Holley, R. (2002) Evaluation of Antilistreial Action of Cilantro Oil on Vacuum Packed Ham. International Journal of Food Microbiology, 73, 83-92. http://dx.doi.org/10.1016/S0168-1605(01)00712-7

[9] Manzanilla, E.G., Baucells, F., Kamel, C., Morales, J., Perez, J.F. and Gasa, J. (2001) Effects of Plant Extracts on the Performance and Lower Gut Microflora of Early Weaned Piglets. Journal of Animal Science, 1, 473. (Abstract).

[10] Gupta, K., Thakral, S., Arora, K. and Chowdhary, M. (1996) Structural Carbohydrate and Mineral Seeds. Indian Coca Arecenut and Species Journal, 20, 120. 
[11] Raju, J., Patlolla, J.M.R., Swamy, M.V. and Rao, C.V. (2004) Diosgenin, a Steroid Saponins of Trigonella foenum graecum (Feungreek), Inhibits Azoxymethane-Induced Aberrant Crypt Foci Formation in F344 Rats and Induces Apoptosis in HT-29 Human Colon Cancer Cells. Cancer Epidemiology, Biomarkers \& Prevention, 13, 1392-1398.

[12] Kolacz, R., Switala, M. and Gajewczyk, P. (1997) Herbs as Agents Affecting the Immunological Status and Growth of Piglets Weaned with Body Weight Deficiency. Journal of Animal and Feed Sciences, 6, 269-279.

[13] Mikaili, P., Mohammad Nezhady, M.A., Shayegh, J. and Asghari, M.H. (2010) Study of Antinociceptive Effect of Thymus vulgaris and Foeniculum vulgare Essential Oil in Mouse. International Journal of Academic Research, 2, 374-376.

[14] Foster, S. and Duke, J. (1999) A Field Guide to Medicinal Plants and Herbs of Eastern and Central North America. Houghton Mifflin Co., Boston, 411.

[15] NRC (National Research Council) (1990) Nutrient Requirements of Poultry. 9th Edition, Academic Press, Washington DC.

[16] SAS Institute (2002) SAS User’s Guide: Statistics, Version 8.0. SAS Institute Inc., Cary.

[17] Murray, R.K., Granner, D.K., Mayes, P. and Rodwell, V.W. (1991) The Text Book of Harpers Biochemistry. 22nd Edition, Appleton and Large, Los Altos.

[18] Toghyani, M., Tohidi, M., Gheisari, A.A. and Tabeidian, S.A. (2010) Performance, Immunity, Serum Biochemical and Hematological Parameters in Broiler Chicks Fed Dietary Thyme as Alternative for an Antibiotic Growth Promoter. African Journal of Biotechnology, 9, 6819-6825.

[19] Najafi, P. and Torki, M. (2010) Performance, Blood Metabolites and Immunocompetence of Broiler Chicks Fed Diets Included Essentioal Oils of Medicinal Herbs. Journal of Animal and Veterinary Advances, 9, 1164-1168. http://dx.doi.org/10.3923/javaa.2010.1164.1168

[20] Tekeli, A., Çelik, L., Kutlu, H.R. and Gorgulu, M. (2006) Effect of Dietary Supplemental Plant Extracts on Performance, Carcass Characteristics, Digestive System Development, Intestinal Microflora and Some Blood Parameters of Broiler Chicks. XII European Poultry Conference, Verona, 10-14 September 2006.

[21] Demir, E., Kilinc, K., Yildirim, Y., Dincer, F. and Eseceli, H. (2008) Comparative Effects of Mint, Sage, Thyme and Flavomycin in Wheat-Based Broiler Diets. Archiva Zootechnica, 11, 54-63.

[22] Ghazalah, A.A. and Ibrahim, A.A. (1996) The Possibility of Using Some Edible and Aromatic Oils in the Nutrition of Muscovi Ducks. Egypt Poultry Science, 11, 305-328.

[23] Abd El-Latif, S.A., El-Yamany, A.T. and Eman, A.F. (2004) Evaluation of Using Different Levels and Sources of Medicinal Herbs in Growing Japanese Quail Diets. Egyptian Journal of Nutrition and Feeds, 7, 69-81.

[24] EL-Gendi, G.M. (1996) Effect of Feeding Dietary Herbal Feed Additives on Productive and Metabolic Responses of Broiler Chicks. Egyptian Poultry Science, 16, 395-412.

[25] Leung, A.Y. and Foster, S. (1996) Encyclopedia of Common Natural Ingredients Used in Food, Drugs and Cosmetics. 2nd Edition, John Wiley and Sons, Inc., New York.

[26] Baratta, M.T., Dorman, H.J.D., Deans, S.G., Biondi, D.M. and Ruberto, G. (1998) Chemical Composition, Antimicrobial and Antioxidative Activity of Laurel, Sage, Rosemary, Oregano and Coriander Essentials Oils. Journal of Essential Oil Research, 10, 618-627. http://dx.doi.org/10.1080/10412905.1998.9700989

[27] Jamroz, D., Orda, J., Kamel, C., Williczkiewicz, A., Wertelecki, T. and Skorupin’Ska, J. (2003) The Influence of Phytogenic Extract on Performance, Nutrients Digestibility, Carcass Characteristic and Gut microbial Status in Broiler Chickens. Journal of Animal Feed Science, 12, 583-596.

[28] Elbushra, M. (2012) Effect of Dietary Fenugreek Seeds (Trigonella foenum) as Natural Feed Addition on Broiler Chicks Performance. Journal of Science and Technology, 13, 27-33.

[29] Abaza, I.M., Shehata, M.S., Shoieb, M.A. and Hssan, I.I. (2008) Evaluation of Some Natural Feed Additives in Growing Chicks Diets. International Journal of Poultry Science, 9, 872-879. http://dx.doi.org/10.3923/ijps.2008.872.879

[30] Ayad, H.S. (1998) Biochemical Studies on Chamomile. M.Sc. Thesis, Biochemistry, Faculty of Agriculture, Cairo University, Giza.

[31] Mansoub, N.H. (2011) Comparison of Effects of Using Nettle (Urtica dioica) and Probiotic on Performance and Serum Composition of Broiler Chickens. Global Veterinaria, 6, 247-250.

[32] Moustafa, K.E.-K. (2006) Effect of Using Commercial and Natural Growth Promoters on the Performance of Commercial Laying Hens. Egyptian Journal of Poultry Science, 26, 941-965.

[33] Abd El-Maksoud, A.A. (2006) Effect of Different Levels of Olive Pulp without or with Kemzyme Supplementation on Laying Hens Performance. Egyptian Journal of Poultry Science, 26, 991-1010.

[34] Issa, K. and Abo Omar, J. (2012) Effect of Garlic Powder on Performance and Lipid Profile of Broilers. Open Journal of Animal Science, 2, 62-68. http://dx.doi.org/10.4236/ojas.2012.22010 